\section{3 結果と考察}

ここに述べた実験では，先に報告した場合1よりも感 度がはるかに増大しているので，主として試料自身の持 つ放射能強度の増大に起因する不つごうを除くため検討

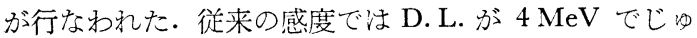
うぶんであったが，ここでは $5 \mathrm{MeV}$ にしなければなら なかった。これ洼来の感度でのマトリックスによる防 害が $4 \mathrm{MeV}$ 以上に注われなかったのに，今回の実験 の感度ではそれを無視しえなかったた为である。

また吸収に関する補正法も改良された。すなわち，透 過率測定用試料調製の際，従来の金属片と紙を交互に重 ねる方式をやめ，ほとえど厚さを無視しうるセロフォン 紙を口紙の代わりに用いて，この試料の軸方向へののび による誤差を防止するようにした。 また，セロフォン紙 が一番下にくる場合とえうで烄い場合の平均值を用いて 酸素の偏在による効果をより減少させた。ストリップ方 式の場合，新たに“透過率”に上る補正法堂採用し従 来の“吸収係数”の代わりとした，以上がすで報告 した方法に対する改良点である。

新しい条件による分析結果を Table I 亿示したが，従 来法（真空融解法）による結果とよく一致している。宋 た，標準偏差は 0.2〜 6.2\% の範囲にあるが，最小值の $0.2 \%$ および最大值の $6.2 \%$ を除外して考えれ伍，他 のものはすべて 2〜4\%の範围にあり，本法の精度は 4\% 程度と考えてよいであろう。また，放射化法の所要時間

Table I Analytical results of oxygen in titanium samples

\begin{tabular}{|c|c|c|c|c|c|}
\hline $\begin{array}{l}\text { Sample } \\
\text { number }\end{array}$ & $\begin{array}{c}\text { Sample } \\
\text { weight } \\
(\mathrm{g})\end{array}$ & $\begin{array}{l}\text { Net } \\
\text { counts }\end{array}$ & $\begin{array}{l}\text { Oxygen } \\
\text { found } \\
(\%)\end{array}$ & $\begin{array}{c}\text { Average } \\
(\%)\end{array}$ & $\begin{array}{l}\text { By } \\
\text { conventional } \\
\text { method }(\%)\end{array}$ \\
\hline Plate-A-7 & 5.134 & $\begin{array}{l}4013 \\
4231 \\
4290\end{array}$ & $\begin{array}{l}0.082 \\
0.087 \\
0.088\end{array}$ & $0.085 \pm 0.003$ & $0.073 \pm 0.007$ \\
\hline Plate- B -7 & 5.288 & $\begin{array}{l}5551 \\
5240 \\
4828 \\
4958\end{array}$ & $\begin{array}{l}0.110 \\
0.104 \\
0.096 \\
0.099\end{array}$ & $0.102 \pm 0.006$ & $0.099 \pm 0.008$ \\
\hline Plate-C-7 & 5.217 & $\begin{array}{l}8762 \\
8426 \\
9191\end{array}$ & $\begin{array}{l}0.176 \\
0.170 \\
0.185\end{array}$ & $0.177 \pm 0.008$ & $0.178 \pm 0.022$ \\
\hline Forgin 211 & 4.895 & $\begin{array}{l}2940 \\
3105 \\
3202 \\
2979 \\
3154\end{array}$ & $\begin{array}{l}0.063 \\
0.067 \\
0.069 \\
0.064 \\
0.068\end{array}$ & $0.066 \pm 0.002$ & $0.067 \pm 0.001$ \\
\hline Forgin 124 & 4.905 & $\begin{array}{l}5798 \\
5792 \\
5813\end{array}$ & $\begin{array}{l}0.124 \\
0.124 \\
0.124\end{array}$ & $0.124 \pm 0.000$ & $0.126 \pm 0.005$ \\
\hline Forgin 342 & 4.961 & $\begin{array}{l}15471 \\
15375 \\
15691 \\
15719 \\
16188\end{array}$ & $\begin{array}{l}0.327 \\
0.325 \\
0.331 \\
0.332 \\
0.342\end{array}$ & $0.331 \pm 0.007$ & $0.311 \pm 0.015$ \\
\hline
\end{tabular}

は，試料の作製および前処理などを別にっれば約 1 分で ある. Table I の場合の感度汶酸絜 $1 \mathrm{mg}$ あたり約 1000 counts であった.

この研究の発表にあたり，真空融解法による分析値 （平均做）の発表を許された日本分析化学会原子炀材料 分析研究愁談会チタン中酸素分析小委員会の委員各位に 感謝する。字た実験汇協力された佐藤正忘氏に感㴬す る.

\section{交献}

1) 藤井 勲，武藤治夫，三好克彦：本誌，13，249 (1964).

2) 藤井 勲, 谷 彰, 武藤治夫，小川一行，传藤 正志：原子力誌，5，218 (1963).

3) I. Fujii, K. Miyoshi, H. Muto, K. Shimura : Anal. Chim. Acta, 34, 146 (1966).

Determination of oxygen in titanium metal by a fast neutron activation method. Isao FujII and Haruo Muto (Central Research Laboratory, Tokyo Shibaura Electric Co., Kawasaki-shi)

The oxygen content of titanium metal was determined by bombarding samples with $14 \mathrm{MeV}$ neutrons from a Cockcroft-Walton machine and measuring the 7.35 second nitrogen-16 gamma activity produced by the reaction ${ }^{16} \mathrm{O}(n, p)^{16} \mathrm{~N}$. In this paper, optimum condition for the measurement of gamma rays of ${ }^{16} \mathrm{~N}$, a correction for the absorption of gamma-rays by samples are discussed. The analytical results by this method are in good agreement with those by the vacuum fusion method. The sensitivity for oxygen is about 1000 counts/mg of oxygen and the standard deviation of the method at the level of oxygen concentration $0.1 \%$ is $4 \%$.

This method may be used to study the accuracy and the precision of the conventional method because the method is non-destructive.

(Received Feb. 28, 1966)

\section{カントメーターによるマグネシウム 合金中の希土類元素の分析}

佐野貞雄, 松井 法*，中川患三**

$$
1 \text { 緒 }
$$

マグネシウム合金中の全金元素はアルミニウム，亜 鈖, マンガン, ジルコニウム, 希土類元㐿, トリウムで

* 神奈川県工業試験所川崎支所：川崎市南幸町 3

** 東京都立大学理学部: 東京都世田谷区深沢町 1 
ある. その合金の種類は希土類元素を含有するものと， 含有しないものに大別できる. 著者らはさきにマグネシ ウム合金中の合金元素, アルミニウム, 亜鉛, マンガン, 古上び不純物元素, 銅, 鉄, ニッケル, 鉛, スズ, ケイ 素の分析について報告しだ).

マグネシウム合金中の希土類元素およびジルコニウム の分析に関しては一，二報告がある233．著者らは金属 電橾を用いる point-to-plane 法によるカントメーター 分析法を確立する目的で研究を行なった結果について報 出亦る。

\section{2 装置および実験条件}

装置汇 A.R.L.の $1.5 \mathrm{~m}$ Industrial Research Quantometer 使用した。発光条件は既報1で述べたように， 会金沉対して最良の結果它与える高圧スパークを使用し キ・ その条件を Table I に示す. 実験した元素とその 淟度範围老 Table II に示す。標準試料は Dow Chemical Co. 製它用いた。

Table I Excitation condition

\begin{tabular}{lcc}
\hline & & High voltage spark \\
\hline Capacitance & $(\mu \mathrm{F})$ & 0.007 \\
Inductance & $(\mu \mathrm{H})$ & 360 \\
Resistance & $(\Omega)$ & residual \\
Voltage & $(\mathrm{kV})$ & 20 \\
Analytical gap & $(\mathrm{mm})$ & 3 \\
Pre-spark & $(\mathrm{sec})$ & 3 \\
Integration time & $(\mathrm{sec})$ & $20^{\circ}$ hemispherical $1 / 4^{\prime \prime}$ graphite \\
Counter-electrode & &
\end{tabular}

Table II Elements and concentration range

\begin{tabular}{cc}
\hline Elements & Concentration range $(\%)$ \\
\hline $\mathrm{La}$ & $0.06 \sim 1.4$ \\
$\mathrm{Ce}$ & $0.04 \sim 1.9$ \\
$\mathrm{Nd}$ & $0.4 \sim 3.5$ \\
$\mathrm{Pr}$ & $0.16 \sim 0.5$ \\
$\mathrm{Zr}$ & $0.4 \sim 0.7$ \\
\hline
\end{tabular}

\section{3 実験㧍よび結果}

希土類元素注遷移元素であり，そのスペクトル線湟 雑である. 一般に希土類元素汁 $3000 \AA$ 以上の波長領域 に感度のよいスペクトル線がある. まず波長表せから， セリウム, ランタン, ネオジム, プラセオジム, ジルコ ニウムの適当な強度を有するスペクトル線をそれぞれ約 20 本選び, 妨害線の存在の有無を調べた. 希土類元素 のスペクトル線は希土類元素相互間の妨害線が多いので 注意する必要がある。
次にそれぞれのスペクトル線について，スペクトル線 強度とバックグラウンドとの比拉よび検量線のこう配を 検討した. その結果, 各元素とも妨害線のない適当な強 度のスペクトル線を選べばよいことがわかった。

Table III に二, 三のスペクトル線についての再現性 を, Fig. 1 に検量線の 1 例を示す.

Table III Precision data

\begin{tabular}{|c|c|c|c|c|}
\hline Elements & Wave length (A) & $\bar{x} \dagger(\%)$ & $\sigma$ & $\nu(\%)$ \\
\hline $\mathrm{Ce}$ II & $\begin{array}{l}4075.85 \\
4289.94 \\
4628.16\end{array}$ & $\begin{array}{l}0.85 \\
0.85 \\
0.86\end{array}$ & $\begin{array}{l}0.0200 \\
0.0189 \\
0.0158\end{array}$ & $\begin{array}{l}2.35 \\
2.22 \\
1.84\end{array}$ \\
\hline $\mathrm{La}$ II & $\begin{array}{l}3794.78 \\
3245.35 \\
3759.08\end{array}$ & $\begin{array}{l}0.59 \\
0.60 \\
0.59\end{array}$ & $\begin{array}{l}0.0170 \\
0.0161 \\
0.0173\end{array}$ & $\begin{array}{l}2.89 \\
3.03 \\
2.94\end{array}$ \\
\hline $\mathrm{Nd} \mathrm{II}$ & $\begin{array}{l}4109.46 \\
4061.09 \\
4303.58\end{array}$ & $\begin{array}{l}0.66 \\
0.67 \\
0.68\end{array}$ & $\begin{array}{l}0.0160 \\
0.0197 \\
0.0141\end{array}$ & $\begin{array}{l}2.42 \\
3.03 \\
2.07\end{array}$ \\
\hline $\operatorname{Pr} \quad$ II & $\begin{array}{l}3964.83 \\
4179.42 \\
4225.33\end{array}$ & $\begin{array}{l}0.22 \\
0.22 \\
0.23\end{array}$ & $\begin{array}{l}0.00654 \\
0.00535 \\
0.00471\end{array}$ & $\begin{array}{l}2.98 \\
2.43 \\
2.05\end{array}$ \\
\hline $\mathrm{Zr} \quad \mathrm{II}$ & $\begin{array}{l}3505.67 \\
3572.47 \\
3279.21\end{array}$ & $\begin{array}{l}0.51 \\
0.52 \\
0.51\end{array}$ & $\begin{array}{l}0.00535 \\
0.01+6 \\
0.01+5\end{array}$ & $\begin{array}{l}1.05 \\
2.81 \\
2.85\end{array}$ \\
\hline
\end{tabular}

$+n=10$.

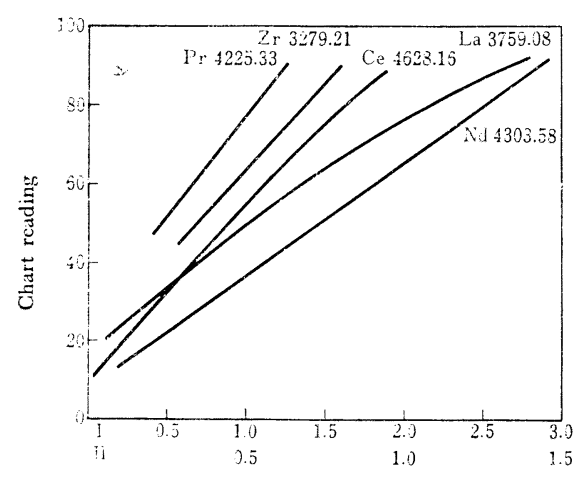

Concentration of (I) Nd, Ce or (II) $\mathrm{La}, \mathrm{Pr}, \mathrm{Zr}, \%$ Fig. 1 Working curves

(昭和 39 年 5 月 21 日, 分析化学討論会ておいて発表)

\section{交献}

1）佐野貞雄, 松井 浩, 中川良三：金属誌, 28, 448 (1964).

2) E. J. Hunemorder, T. M. Hess : Anal. Chem., 29, 236 (1957).

3) A.S. T. M. "Method for Emission Spectrochemical Analysis", p. 500 (1964).

4) "Tables of Spectral-line Intensities", NBS Monograph 32-part I. 
Quantometric analysis of rare earth elements in magnesium alloys. Sadao SANo, Hiroshi MAtsui and Ryozo Nakagawa (Kawasaki Branch, Industrial Research Institute of Kanagawa Prefecture, Kawasakishi)

Using A R L's $1.5 \mathrm{~m}$ Industrial Research Quantometer, analyses of rare earth elements and zirconium in magnesium alloys have been carried out by the pointto-plane method. High voltage spark discharge $(L=$ $360 \mu \mathrm{H}, C=0.007 \mu \mathrm{F}, R=$ residual, $V=20 \mathrm{kV}$ ) is used for excitation. Elements analysed and the range of their concentration are : $\mathrm{La} 0.06 \sim 1.4 \%$, Ce $0.04 \sim$ $1.9 \%, \operatorname{Pr} 0.16 \sim 0.5 \%, \mathrm{Nd} 0.4 \sim 3.5 \%$ and $\mathrm{Zr} \quad 0.4 \sim$ $0.7 \%$, and these elements are determined with the coefficient in the variation of about $1 \sim 3 \%$.

(Received Mar. 21, 1966)

\section{定性分析第 IV 属陽イオンの硫化物沈殿 の ESR}

藤原鎮男，長島弘三，小林大機*

定性分析活いて第IV 属陽イオンは, アンモニアア ルカリ性て硫化物として沈殿させたのち，沈殿を希塩酸 で処理する之，亜鉛，マンガンは溶解するが，コバル ト，ニッケルは不溶物として残るので相互に分離され る.種々の割合で (1) 亜鉛ーマンガン，(2) コバルトー マンガン点导硫化物沈殿をつくり，ESR に上り沈殿 円のマンガンの分布状態を調べた。マンガンは（1）に 昉いても（2）に颃いても，均一に分布していることが わ放叔。

\section{1 緒言}

少量のマンガン（II）イオンがイオン結合的な固体化 合物中に存在するとき，それが分散して存在す机ば（結 晶質の化合物のときは固溶していれば)，6本の超微細 構造（hfs） え有する ESR シグナルを与えるが，マンガ ン（II）イオンがやや集まって存在すると，双極子相互 作用の結果，hfs は見られなくなり，広幅の単シグナル 在与える。著者らは，この現象を利用し，天然㧍よび人 工の炭酸カルシウム中のマンガン (II) の分布 ${ }^{1)}$, 各種 の金属オキシン塩と銅（II）オキシン塩の固溶体生成の 有無つ学検討してきた。ここでは亜鉛と少量のマンガ ン，拉よびコバルトと少量のマンガンを含む溶液から硫
化物を沈殿させ, 得られた沈殿の ESR の観察結果につ いて述べる.

硫化物中のマンガン (II) の ESR は $\mathrm{ZnS}_{\mathrm{hex}^{3}}$ およ び $\mathrm{ZnS}_{\mathrm{cub}}{ }^{4)}$ 中の微量のマンガンの $\mathrm{ESR}$ が観測報告さ れている.両者いずれも 6 本の hfs を与克，磁気パラメ ーターは $\mathrm{g}=2.0024 \pm 0.0004, \mathrm{~A}=67.4$ ガウス $\left(\mathrm{ZnS}_{\mathrm{hex}}\right.$ 中) $)^{3)}, \mathrm{A}=68.4$ ガウス $\left(\mathrm{ZnS}_{\mathrm{cub}} \text { 中) }\right)^{4)}$ である. 後述す るように，通常の手法で作った亜鉛，マンガン，コバル ト，ニッケルの硫化物沈殿は，いずれもX線的に無定形 であるが，硫化亜鉛や硫化コバルト中に分散させたマン ガン（II）の磁気パラメーターは，上記の值と異なって おり， $\mathrm{A}=71.6$ ガウスである.

第IV 属硫化物沈殿を希塩酸で処理すると，亜鉛とマ ンガンは溶出し，コバルトとニッケルは不溶物として残 るのであるから，マンガンを主として考光るとき，沈殿 中で硫化マンガンと硫化亜鉛は 1 相であってもよい心゙， 硫化マンガンと硫化コバルトまたは硫化ニッケル法 2 相 であって，そのうちの硫化マンガンのみが希塩酸に溶汸 るものと予想した．ESR による検討の結果は，この予 想に反し, 少量のマンガンは, 硫化亜鉛, 硫化コバルト のいずれとも固溶（X線的汇無定形であるからこのこ とばは適当でないかもし机ないが，固相中に均一に分有 しているという意味で以下に用いる）することがれぶ た。

\section{2 実験および結果}

\section{$2 \cdot 1$ 装置および試薬}

ESR スペクトロメーター：日本電子製 JES 118 型， 発振周波数 9400 メガサイクル。

試薬はすべて市販の特級品を用いた。亜鉛, マンガ ンコバルト，ニッケル（硫酸塩または硝酸塩）の溶液 の濃度は EDTA 滴宫によって決定した。硫化アンモニ ウムは 1:4 のアンモニア水に硫化水素をじゅうぶえ通 して調製した。

\section{$2 \cdot 2$ 混合硫化物沈殿の調製}

全金属原子中のマンガンのモル \%が，0.01，0.03， $0.06 ， 0.1 ， 0.3 ， 0.6 ， 1.0 ， 3.0 ， 6.0 \%$ になるように， 亜鉛，コバルト，ニッケルの各水溶液とマンガン水溶液 を混合し，標準列を作った。おのおのにかき混ぜながら 硫化アンモニウム溶液を滴下して，硫化物の沈殿を生成 させた

この沈殿物中のマンガンの存在状態它 ESR で測定す るのであるが，湿った試料中ではシグナルを観測しにく いので，試料を乾燥する必要がある。また硫化物は空気 中では不安定で，硫化マンガン（II）は，容易に酸化气 